\title{
Dietary (n-6 : n-3) Fatty Acids Alter Plasma and Tissue Fatty Acid Composition in Pregnant Sprague Dawley Rats
}

\author{
Amira Abdulbari Kassem,, ${ }^{1,2}$ Md Zuki Abu Bakar, ${ }^{1}$ Goh Yong Meng, ${ }^{1}$ \\ and Noordin Mohamed Mustapha ${ }^{3}$ \\ ${ }^{1}$ Department of Veterinary Preclinical Sciences, Faculty of Veterinary Medicine, Universiti Putra Malaysia, \\ 43400 UPM Serdang, Selangor, Malaysia \\ ${ }^{2}$ Department of Animal Production, Faculty of Agriculture, University of Sana'a, P.O. Box 12426, Sana'a, Yemen \\ ${ }^{3}$ Department of Pathology and Microbiology Veterinary, Faculty of Veterinary Medicine, Universiti Putra Malaysia, \\ 43400 UPM Serdang, Selangor, Malaysia
}

Correspondence should be addressed to Amira Abdulbari Kassem, amirabarialika@gmail.com

Received 27 October 2011; Accepted 12 December 2011

Academic Editor: John F. Mee

Copyright (C) 2012 Amira Abdulbari Kassem et al. This is an open access article distributed under the Creative Commons Attribution License, which permits unrestricted use, distribution, and reproduction in any medium, provided the original work is properly cited.

\begin{abstract}
The objective of this paper is to study the effects of varying dietary levels of $n-6: n-3$ fatty acid ratio on plasma and tissue fatty acid composition in rat. The treatment groups included control rats fed chow diet only, rats fed 50\% soybean oil (SBO): $50 \%$ cod liver oil (CLO) (1:1), 84\% SBO: 16\% CLO (6:1), 96\% SBO: 4\% CLO (30:1). Blood samples were taken at day 15 of pregnancy, and the plasma and tissue were analyzed for fatty acid profile. The n-3 PUFA in plasma of Diet 1:1 group was significantly higher than the other diet groups, while the total $n$-6 PUFA in plasma was significantly higher in Diet 30:1 group as compared to the control and Diet $1: 1$ groups. The Diet $1: 1$ group showed significantly greater percentages of total $n-3$ PUFA and docosahexaenoic acid in adipose and liver tissue, and this clearly reflected the contribution of $n-3$ fatty acids from CLO. The total $n$ - 6 PUFA, linoleic acid, and arachidonic acid were significantly difference in Diet $30: 1$ as compared to Diet $1: 1$ and control group. These results demonstrated that the dietary ratio of $n-6: n-3$ fatty acid ratio significantly affected plasma and tissue fatty acids profile in pregnant rat.
\end{abstract}

\section{Introduction}

Fatty acids perform two major physiological roles in mammalian tissues: a structural role and a role in energy storage and production. First, fatty acids are the units of phospholipids and glycolipids and, therefore, important constituents of biological membranes. In fact, the fatty acid chains are more than half the mass of most major phospholipids and they are primarily responsible for the apolar nature of the membrane bilayer [1]. The composition of dietary fat is extremely important in the metabolism of PUFA in body tissues, because each dietary fatty acid will influence the utilization of other fatty acids [2]. Linoleic acid, ALA, and oleic acid (nonessential) are competitive substrates for the same sequence of desaturation enzymes. The affinity of these fatty acids for the desaturation enzymes is as follows: ALA > LA > oleic acid. Low concentrations of ALA are very effective in suppressing the metabolism of LA. However, moderate levels of LA are necessary to inhibit the metabolism of ALA, whereas only high concentrations of oleic acid can suppress the metabolism of LA. Consequently, the metabolites of ALA and LA are normally found in higher amounts than the metabolites of oleic acid in normal body tissues and fluids. Because the dietary fat composition can be altered in favor of one of the above fatty acids, the metabolism can be shifted according to the affinity, as well as the amount of fatty acid consumed. Therefore, dietary intake determines to a great extent the fatty acid composition of phospholipids in the plasma, tissues, and cell membranes [3]. The plasma and adipose tissue FA composition reflect the composition of the diet to a large extent, but they also reflect de novo FA synthesis coupled with chain elongation and desaturation [4]. This process occurs in the liver, mammary gland, and adipose tissue. Fatty acids can also be altered by desaturation or 
elongation reactions, which mainly occur in the liver [5]. Numerous studies have associated alterations in dietary fats of maternal diet during pregnancy or during weaning period with alterations in fatty acid composition of cell membranes and organelles in brain and behavioral deficits in rats and mice [6], and the DHA is important in normal brain development and function because it is positively correlates with the changes in cognitive and behavioural performance [7]. The objective of this study was to assess the effect of dietary fatty acids supplementation on plasma and membrane fatty acid composition of the liver and adipose tissues.

\section{Materials and Methods}

2.1. Animals and Experimental Design. Twenty-eight (28) female, two-month-old Sprague-Dawley $(240 \pm 20 \mathrm{~g}$ body weight) rats were used in this experiment. After 2 weeks of adaptation, the rats were randomly divided into four treatment groups consisting of seven rats in each group. The experiment was approved by Institutional Animal Care and Use Committee (IACUC) of Faculty of Veterinary Medicine Universiti Putra Malaysia. The cod liver oil (Seven seas, Malaysia) was used as the main source of $n$ - 3 PUFA (Eicosapentaenoic acid (EPA) and docosahexaenoic acid (DHA)) and soybean oil is the main source of $n-6$ fatty acids and linolenic acid (LA). The SBO and CLO were first analysed to determine the fatty acid profile and are shown in Table 1. The initial body weight of each rat was recorded, and during the whole experiment the body weight and feed intake of each rat were taken every week. After adaptation period, the rats were randomly assigned to dietary treatments. The treatment groups include rats fed with normal rat chow diet the control (C) group, rats fed chow diet supplemented with 5\% (w/w) SBO and 5\% (w/w) CLO (Diet 1:1 group), rats fed chow diet added with $8.4 \%(\mathrm{w} / \mathrm{w}) \mathrm{SBO}$ and $1.6 \%$ (w/w) CLO (Diet 6:1 group), and rats fed chow diet added with 9.6\% (w/w) SBO and 0.4\% (w/w) CLO (Diet 30:1 group). The rats were fed $7 \%$ of body weight daily, and water was provided ad libitum. The diets were prepared daily to minimize rancidity and oxidative damage the rats were fed once daily and the leftover feeds were collected before new feeding. After two months of feeding trial, daily vaginal smears were taken and examined immediately to determine the estrous cycle of each rat. The pregnancy was induced by overnight caging of a proestrus female with a male of proven fertility. The next day, the presence of a vaginal plug or spermatozoa in the vaginal smear was termed as day 0 of pregnancy. Pregnant females were separated from the male rats after confirmation of pregnancy. The rat were individually housed in polycarbonate cages $(43 \times 28 \times 16 \mathrm{~cm})$ with sawdust bedding, in controlled room temperature $\left(23 \pm 2{ }^{\circ} \mathrm{C}\right)$ with $12 \mathrm{~h}$ of light and $12 \mathrm{~h}$ of darkness. At day 15 th of each pregnancy, rats were anesthetized with an intraperitoneal injection of ketamine $60 \mathrm{mg} / \mathrm{kg}$ body weight (Narketan Vetoquinol SA, 70204 Lure, Sedex, France) + xylazine $8 \mathrm{mg} / \mathrm{kg}$ body weight (Troy Laboratory PTY Ltd, Australia) and blood was collected via cardiac puncture using 26 gauge needle. Before collecting the blood, the syringe was coated with EDTA to prevent blood clotting within the syringe. The blood collected was placed in EDTA and immediately placed on ice. Samples were labeled for identification and centrifuged at $3000 \mathrm{G}$ for $10 \mathrm{~min}$ plasma was removed and stored at $-80^{\circ} \mathrm{C}$ until analysed within one week. Thereafter, the rats were immediately sacrificed. In addition, following exsanguinations, about $2 \mathrm{~g}$ each of liver and abdominal adipose tissue was collected and kept at $-20^{\circ} \mathrm{C}$ until subsequent analysis.

2.2. Fatty Acids Determination. The total fatty acids were extracted from feeds and tissue based on the method of [8], modified by [9], using chloroform: methanol $2: 1$ (v/v) containing butylated hydroxytoluene to prevent oxidation during sample preparation. The experimental diets or tissues were homogenized in $40 \mathrm{~mL}$ chloroform: methanol $(2: 1$ $\mathrm{v} / \mathrm{v})$. The mixture containing the extracted fatty acids was filtered through No. 1 Whatman paper (Whatman International Ltd., Maidstone, UK) into a $250 \mathrm{~mL}$ separating funnel using a funnel. Ten (10) $\mathrm{mL}$ of normal saline solutions were added to facilitate phase separation. The mixture was then shaken vigorously for one minute and was left to stand for four hours. After complete separation at the end of the fourth hour, the upper phase was discarded and the lower phase was collected in a round bottom flask and evaporated via rotary evaporation (Laborota 4000-efficient, Heidolph, Germany) at $70^{\circ} \mathrm{C}$.

The total lipid extract was then immediately transferred into a capped methylation tube by rediluting it with $5 \mathrm{~mL}$ fresh chloroform : methanol $(2: 1, \mathrm{v} / \mathrm{v})$. Transmethylation of the extracted fatty acids to their fatty acid methyl esters (FAME) was carried out using 14\% methanolic boron trifluoride (BF3) (Sigma Chemical Co., St. Louis, MO, USA) according to methods in AOAC (1990). The internal standard, heneicosanoic acid (21:0) (Sigma Chemical Co., St. Louis, Mo, USA), was added to each sample prior to transmethylation to determine the individual fatty acid concentrations within the samples. The methyl esters were quantified by Gas Chromatography (GC) (Agilent $7890 \mathrm{~N}$ ) using a $30 \mathrm{~m} \times 0.25 \mathrm{~mm}$ ID $(0.20 \mu \mathrm{m}$ film thickness $)$ Supelco SP-2330 capillary column (Supelco, Inc., Bellefonte, PA, USA). One microliter of fatty acid methyl ester (FAME) was injected by an autosampler into the chromatograph, equipped with a split/splitless injector and a flame ionization detector (FID). The injector temperature was programmed at $250^{\circ} \mathrm{C}$, and the detector temperature was $300^{\circ} \mathrm{C}$. The initial column temperature was set at $100^{\circ} \mathrm{C}$ for $2 \mathrm{~min}$, and then increased at $10^{\circ} \mathrm{C} / \mathrm{min}$ to $170^{\circ} \mathrm{C}$ where it was held for another $2 \mathrm{~min}$. Finally, it was warmed to $220^{\circ} \mathrm{C}$ at $7.5^{\circ} \mathrm{C} / \mathrm{min}$ to reach a final temperature of $250^{\circ} \mathrm{C}$ and held for $20 \mathrm{~min}$ to facilitate optimal separation. All results of fatty acid presented as the percentage of total fatty acids.

2.3. Data Analysis. Data were analysed as a completely randomized design experiment using the General Linear Model of SAS 9.02 software (Statistical Analysis Systems Institute Inc., 1992). The fatty acid profiles of the rat treatment diets and different tissue were analysed across treatment groups using the one-way analysis of variance (ANOVA) method. Significantly different means were then elucidated using the 
TABle 1: Fatty acid composition ( $\mathrm{g} / 100 \mathrm{~g}$ total fatty acids) of the treatment diets $(n=3)$.

\begin{tabular}{|c|c|c|c|c|}
\hline \multirow{2}{*}{ Fatty acid composition (g/100 g) of feed sample } & \multicolumn{4}{|c|}{ Group } \\
\hline & $\operatorname{Diet}(1: 1)$ & $\operatorname{Diet}(6: 1)$ & $\operatorname{Diet}(30: 1)$ & Diet (control) \\
\hline C14: 0 myristic acid & 2.22 & 1.03 & 0.41 & 1.47 \\
\hline $\mathrm{C} 16: 0$ palmitic acid & 14.55 & 13.43 & 12.94 & 16.14 \\
\hline C16:1 palmitoleic acid & 2.48 & 1.12 & 0.40 & 0.54 \\
\hline C17: 0 heptadecanoic acid & 0.72 & 1.03 & 0.53 & 1.02 \\
\hline $\mathrm{C} 18: 0$ stearic acid & 3.99 & 4.26 & 4.27 & 3.73 \\
\hline C18: 1 oleic acid & 25.51 & 27.08 & 26.65 & 26.42 \\
\hline C18: $2 n-6$ linoleic acid (LA) & 34.88 & 43.08 & 47.70 & 40.75 \\
\hline C18:3n-3 linolenic acid (ALA) & 0.70 & 0.54 & 0.77 & 0.68 \\
\hline $\mathrm{C} 20: 0$ arachidic acid & 3.94 & 4.87 & 4.96 & 3.80 \\
\hline C20 : $4 n-6$ arachidonic acid & 3.83 & 1.52 & 0.32 & 1.95 \\
\hline C20: $5 n$-3 ecosapentaenoic acid & 3.41 & 0.94 & 0.39 & $\mathrm{Nd}$ \\
\hline C22: $6 n-3$ docosahexaenoic acid & 3.77 & 1.08 & 0.65 & $\mathrm{Nd}$ \\
\hline Total saturated fatty acid & 25.42 & 24.60 & 23.78 & 26.15 \\
\hline Total unsaturated fatty acid & 74.58 & 75.40 & 76.22 & 73.85 \\
\hline Total MUFA fatty acid & 27.99 & 28.40 & 27.05 & 30.46 \\
\hline Total PUFA $n-3$ & 7.87 & 2.40 & 1.15 & 0.68 \\
\hline Total PUFA $n-6$ & 38.72 & 44.60 & 48.03 & 42.70 \\
\hline$n-6: n-3$ ratio & 4.92 & 18.20 & 44.80 & 64.29 \\
\hline Unsat: Sat & 2.93 & 3.06 & 3.21 & 2.86 \\
\hline Poly: Sat ratio & 1.83 & 1.92 & 2.07 & 1.67 \\
\hline
\end{tabular}

$\sum \mathrm{SFA}=$ sum of $\mathrm{C} 10: 0, \mathrm{C} 12: 0, \mathrm{C} 14: 0, \mathrm{C} 15: 0, \mathrm{C} 16: 0, \mathrm{C} 17: 0, \mathrm{C} 18: 0, \mathrm{C} 20: 0$.

$\sum$ MUFA $=$ sum of $\mathrm{C} 14: 1, \mathrm{C} 16: 1, \mathrm{C} 18: 1$.

$\sum$ PUFA $n-6=\mathrm{C} 18: 2 n-6, \mathrm{C} 20: 4 n-6$.

$\sum$ PUFA $n-3=\mathrm{C} 18: 3 n-3, \mathrm{C} 22: 6 n-3$.

$n-6 / n-3=(\mathrm{C} 18: 2 n-6+\mathrm{C} 20: 4 n-6) /(\mathrm{C} 18: 3 n-3+\mathrm{C} 22: 6 n-3)$.

Duncan's multiple range tests. All statistics were performed at $95 \%$ confidence.

\section{Result}

3.1. Fatty Acids Profile of Treatment Diets. The fatty acid profiles of treatment diets are summarized in Table 1. These diets contain both the $n-6$ (LA) and n-3 (ALA) essential fatty acids (EFA). Diet 30:1 was used to reflect the higher dietary fat intake of a western human diet, while maintaining the relative contributions of LA and ALA observed in the $1: 1$.

Using high level of SO (30:1 ratio), the total $n$ - 6 PUFA increased in the Diet $30: 1(48.03 \mathrm{~g} / 100 \mathrm{~g})$, while using high level of CLO (1:1 ratio), the total $n-3$ PUFA increased in Diet $1: 1(7.87 \mathrm{~g} / 100 \mathrm{~g})$. The $n-6: n-3$ ratio increased progressively from 4.92 in Diet $1: 1$ to 44.80 in Diet $30: 1$ and 64.29 in Diet Control. Diet 30:1 contained highest linoleic acid (18:2n-6), which was the major fatty acid, while Diet $1: 1$ contained highest ALA $(18: 3 n-3)$. The major fatty acids content of Diet 6:1 was always in between the Diet $1: 1$ and Diet $30: 1$.

3.2. Fatty Acids Profile of Plasma. Table 2 showed the plasma fatty acids profiles of the rats treated with different diets after 10 weeks of feeding trial. In the current experiment, 22 fatty acids were detected in plasma. Plasma fatty acids profiles of the Diet $6: 1$ and Diet $30: 1$ groups showed significantly greater $(P<0.05)$ percentages of total $n-6$ PUFA as compared to Diet $1: 1$ and Diet Control groups. Arachidonic acid (AA) was significantly higher $(P<0.05)$ in Diet $6: 1$ and Diet $30: 1$ group as compared to Diet $1: 1$ group. Diet $1: 1$ group had the highest value of eicosapentaenoic acid (EPA) and docosahexaenoic acid (DPA) in comparison to Diet $6: 1$ and Diet $30: 1$ groups. The plasma total PUFA $n-3$ fatty acid in Diet $1: 1$ group was the highest at $11.21 \%(P<0.05)$, and this clearly reflected the contribution of $n-3$ fatty acids from CLO. Linoleic acid (LA) was the main unsaturated fatty acid in the plasma of all diet groups. The $n-6: n-3$ ratio was significantly lower $(3.49 \%)$ in the Diet $1: 1$ group $(P<0.05)$ as compared to other groups. Both the Diet 6:1 and Diet $30: 1$ groups had almost similar amount $(P>0.05)$ of $n-6: n-3$ ratios. The $n$ $6: n-3$ ratio was in the increasing order starting from Diet $1: 1$, Diet $6: 1$, Diet $30: 1$, and Diet Control groups.

3.3. Liver Tissue Fatty Acids Composition. Table 3 showed the liver tissue fatty acids profiles of the rats treated with different diets after 10 weeks of feeding trial. The Diet $1: 1$ group demonstrated the lowest $\alpha$-Linolenic acid (ALA, 18:3, $n-3)$ and highest docosahexaenoic acid (DHA, 22:6,n-3) contents in the liver lipid fractions examined. There was also a higher content of Ecosapentaenoic acid (EPA; $22: 5, n-3)$ in 
TABLE 2: Plasma fatty acid composition ( $\mathrm{mg} / 100 \mathrm{~mL}$; Mean \pm SE; $n=7)$ of rats from different treatment groups after 10 weeks of feeding.

\begin{tabular}{|c|c|c|c|c|}
\hline \multirow{2}{*}{ Fatty acid composition $(\mathrm{g} / 100 \mathrm{~mL})$ of plasma } & \multicolumn{4}{|c|}{ Group } \\
\hline & $\operatorname{Diet}(1: 1)$ & $\operatorname{Diet}(6: 1)$ & $\operatorname{Diet}(30: 1)$ & Diet (control) \\
\hline C12: 0 lauric acid & $2.25 \pm 0.28^{\mathrm{a}}$ & $1.02 \pm 0.16^{\mathrm{b}}$ & $1.84 \pm 0.09^{\mathrm{a}}$ & $0.56 \pm 0.19^{\mathrm{b}}$ \\
\hline C14: 0 myristic acid & $1.31 \pm 0.33^{\mathrm{a}}$ & $1.19 \pm 0.41^{\mathrm{a}}$ & $\mathrm{Nd}$ & $0.53 \pm 0.11^{\mathrm{b}}$ \\
\hline C15: 0 pentadecanoic acid & $1.66 \pm 0.30^{\mathrm{a}}$ & $1.67 \pm 0.28^{\mathrm{a}}$ & $1.12 \pm 0.19^{\mathrm{a}}$ & $0.41 \pm 0.05^{\mathrm{b}}$ \\
\hline $\mathrm{C} 16: 0$ palmitic acid & $15.53 \pm 0.80^{\mathrm{b}}$ & $12.04 \pm 0.83^{\mathrm{b}}$ & $13.75 \pm 1.07^{\mathrm{b}}$ & $21.67 \pm 2.11^{\mathrm{a}}$ \\
\hline $\mathrm{C} 16: 1$ palmitoleic acid & $0.50 \pm 0.05^{\mathrm{b}}$ & $0.94 \pm 0.15^{\mathrm{ab}}$ & $0.72 \pm 0.14^{\mathrm{ab}}$ & $1.27 \pm 0.22^{\mathrm{a}}$ \\
\hline C17: 0 heptadecanoic acid & $14.55 \pm 0.36^{\mathrm{ab}}$ & $14.76 \pm 0.70^{\mathrm{a}}$ & $13.83 \pm 0.89^{\mathrm{ab}}$ & $12.20 \pm 0.90^{\mathrm{b}}$ \\
\hline $\mathrm{C} 18: 0$ stearic acid & $10.34 \pm 0.90^{\mathrm{b}}$ & $8.93 \pm 1.30^{\mathrm{b}}$ & $9.88 \pm 1.42^{\mathrm{b}}$ & $14.93 \pm 1.23^{\mathrm{a}}$ \\
\hline C18: 1 oleic acid & $0.66 \pm 0.05^{\mathrm{ns}}$ & $0.77 \pm 0.10^{\mathrm{ns}}$ & $1.06 \pm 0.23^{\mathrm{ns}}$ & $1.11 \pm 0.24^{\mathrm{ns}}$ \\
\hline C18:2 n-6 linoleic acid & $24.85 \pm 0.95^{\mathrm{ns}}$ & $23.06 \pm 1.45^{\mathrm{ns}}$ & $24.93 \pm 2.48^{\mathrm{ns}}$ & $24.21 \pm 1.02^{\mathrm{ns}}$ \\
\hline $\mathrm{C} 20: 0$ arachidic acid & $0.70 \pm 0.04^{\mathrm{ns}}$ & $0.77 \pm 0.11^{\mathrm{ns}}$ & $0.75 \pm 0.10^{\mathrm{ns}}$ & $\mathrm{Nd}$ \\
\hline $\mathrm{C} 20: 4 n-6$ arachidonic acid & $13.94 \pm 1.32^{b}$ & $22.62 \pm 1.66^{\mathrm{a}}$ & $23.43 \pm 2.14^{\mathrm{a}}$ & $19.58 \pm 2.42^{\mathrm{ab}}$ \\
\hline $\mathrm{C} 20: 5 n$-3 eicosapentaenoic acid & $3.82 \pm 0.72^{\mathrm{a}}$ & $3.05 \pm 0.34^{\mathrm{ab}}$ & $1.73 \pm 0.58^{\mathrm{b}}$ & $\mathrm{Nd}$ \\
\hline C22: $5 n-3$ docosapentaenoic acid & $0.90 \pm 0.26^{\mathrm{a}}$ & $0.59 \pm 0.24^{\mathrm{b}}$ & $0.32 \pm 0.14^{\mathrm{b}}$ & $\mathrm{Nd}$ \\
\hline C22: $6 n-3$ docosahexaenoic acid & $6.49 \pm 0.47^{\mathrm{a}}$ & $4.22 \pm 0.57^{\mathrm{b}}$ & $4.33 \pm 0.64^{\mathrm{b}}$ & $2.09 \pm 0.15^{\mathrm{c}}$ \\
\hline Total saturated & $37.32 \pm 1.00^{\mathrm{a}}$ & $33.16 \pm 0.42^{\mathrm{b}}$ & $33.19 \pm 0.77^{\mathrm{b}}$ & $36.48 \pm 1.40^{\mathrm{a}}$ \\
\hline Total unsaturated & $62.68 \pm 1.00^{\mathrm{b}}$ & $66.84 \pm 0.42^{\mathrm{a}}$ & $66.81 \pm 0.77^{\mathrm{a}}$ & $63.52 \pm 1.40^{\mathrm{b}}$ \\
\hline Total monoenes & $12.69 \pm 0.80^{\mathrm{b}}$ & $12.50 \pm 1.51^{\mathrm{b}}$ & $12.88 \pm 1.40^{\mathrm{b}}$ & $17.65 \pm 1.14^{\mathrm{a}}$ \\
\hline Total PUFA $n-3$ & $11.21 \pm 0.49^{\mathrm{a}}$ & $7.85 \pm 0.54^{\mathrm{b}}$ & $6.38 \pm 1.00^{\mathrm{b}}$ & $2.09 \pm 0.15^{c}$ \\
\hline Total PUFA $n-6$ & $38.79 \pm 0.42^{b c}$ & $46.49 \pm 1.54^{\mathrm{a}}$ & $47.55 \pm 1.17^{\mathrm{a}}$ & $43.79 \pm 1.51^{\mathrm{b}}$ \\
\hline$n-6: n-3$ ratio & $3.49 \pm 0.17^{\mathrm{c}}$ & $6.05 \pm 0.54^{\mathrm{bc}}$ & $8.79 \pm 2.16^{\mathrm{b}}$ & $21.36 \pm 1.44^{\mathrm{a}}$ \\
\hline Unsat: Sat & $1.69 \pm 0.07^{\mathrm{ns}}$ & $2.02 \pm 0.04^{\mathrm{ns}}$ & $2.02 \pm 0.07^{\mathrm{ns}}$ & $1.76 \pm 0.10^{\mathrm{ns}}$ \\
\hline Poly: Sat ratio & $1.34 \pm 0.05^{\mathrm{b}}$ & $1.64 \pm 0.06^{\mathrm{a}}$ & $1.63 \pm 0.09^{a}$ & $1.27 \pm 0.08^{\mathrm{b}}$ \\
\hline
\end{tabular}

Values with different superscripts within rows are significantly different at $P<0.05$; ${ }^{\text {ns }}$ no significant difference; ND: not detected.

the liver lipids of Diet $1: 1$ group as compared to the other groups (Table 3 ).

The total $n$-3 PUFA was significantly higher in the Diet $1: 1$ group as compared to other groups. The total saturated, unsaturated, and monounsaturated fatty acids were not significantly different $(P>0.05)$ among the groups. Total percentage of DHA in the Diet $1: 1$ group was increased as compared to other groups, but not significantly different $(P>$ $0.05)$. The percentage of total $n-6$ PUFA was not significantly different $(P>0.05)$ among the groups. No significant differences were observed for the $n-6: n-3$ ratio, Unsat: Sat and Poly: Sat ratios among the treatment groups.

3.4. Adipose Tissue Fatty Acids Composition. Table 4 showed the adipose tissues fatty acids profiles of the rats treated with different diets after 10 weeks of feeding trial. Dietary fatty acids supplementation had significant effects on the fatty acids composition of the adipose tissue. The Diet $1: 1$ group showed significantly greater $(P<0.05)$ percentages of total $n-3$ PUFA and docosahexaenoic acid (DHA) as compared to other groups, and this clearly reflected the contribution of $n$ 3 fatty acids from CLO. The percentages of total n-6 PUFA, linoleic acid (LA), and arachidonic acid (AA) were significantly different $(P<0.05)$ in Diet 30:1 as compared to Diet $1: 1$ and Diet Control groups, but not significantly different when compared with Diet $6: 1$ group.
In the Diet $1: 1$ group, decreased level of AA was observed as compared to the Diet 30:1 group. The total unsaturated fatty acids (UFA) in the Diet Control was significantly decreased $(P<0.05)$ as compared to other treatment groups. Rats fed with Diet $1: 1$ and Diet 6:1 had significantly higher adipose total UFA as compared to the control group, but significantly lower than the Diet 30:1 group. However, the percentages of Unsat: Sat and Poly: Sat ratio were significantly higher $(P<0.05)$ in the Diet $30: 1$ group as compared to other groups.

\section{Discussion}

Fatty acids composition of a diet is known to influence the fatty acid composition of stored and structural lipids in the body [3]. The current study showed the close link between dietary and tissue fatty acids constitution. This diet contains both $n-6$ and $n-3$ EFA (LA and ALA). The high dietary n-6: $n-3$ ratio soyabean oil diet was used to reflect the higher dietary fat intake of a western human diet, while maintaining the relative contributions of LA and ALA observed in the low dietary $n-6: n-3$ ratio soyabean oil diet. Diet had a significant effect on the fatty acid composition of all plasma fatty acids. The low ratio in Diet 1:1 (ALA-rich) group had significantly higher AlA content of plasma fatty acids profiles. The content of LC n-3 PUFA was also affected by diet. The cod liver oil on Diet $1: 1$ groups had the highest EPA content in plasma fatty 
TABLE 3: Liver tissue fatty acid composition ( $\mathrm{mg} / 100 \mathrm{~mL}$; Mean $\pm \mathrm{SE} ; n=7)$ of rats from diffrent treatment groups after 10 weeks of feeding.

\begin{tabular}{|c|c|c|c|c|}
\hline \multirow{2}{*}{ Fatty acid composition of sample (mg/100 g) } & \multicolumn{4}{|c|}{ Group } \\
\hline & $\operatorname{Diet}(1: 1)$ & $\operatorname{Diet}(6: 1)$ & $\operatorname{Diet}(30: 1)$ & Diet (control) \\
\hline $12: 0$ lauric acid & $0.03 \pm 0.00^{c}$ & $0.22 \pm 0.04^{\mathrm{a}}$ & $0.12 \pm 0.04^{\mathrm{b}}$ & $0.08 \pm 0.02^{\mathrm{bc}}$ \\
\hline $14: 0$ myristic acid & $0.18 \pm 0.02^{\mathrm{a}}$ & $0.18 \pm 0.03^{\mathrm{a}}$ & $0.15 \pm 0.02^{\mathrm{a}}$ & $0.15 \pm 0.02^{\mathrm{a}}$ \\
\hline $16: 0$ palmitic acid & $16.90 \pm 0.37^{\mathrm{a}}$ & $16.61 \pm 0.58^{\mathrm{a}}$ & $16.45 \pm 0.56^{\mathrm{a}}$ & $15.96 \pm 0.20^{\mathrm{a}}$ \\
\hline $16: 1$ palmitoleic acid & $0.35 \pm 0.05^{\mathrm{a}}$ & $0.39 \pm 0.09^{\mathrm{a}}$ & $0.23 \pm 0.04^{\mathrm{a}}$ & $0.21 \pm 0.04^{\mathrm{a}}$ \\
\hline $18: 0$ stearic acid & $21.81 \pm 0.87^{\mathrm{b}}$ & $23.94 \pm 0.60^{\mathrm{b}}$ & $24.22 \pm 0.70^{\mathrm{a}}$ & $24.64 \pm 0.38^{\mathrm{a}}$ \\
\hline $18: 1$ oleic acid & $7.36 \pm 0.70^{\mathrm{a}}$ & $6.20 \pm 0.79^{b}$ & $6.07 \pm 0.32^{\mathrm{ab}}$ & $5.15 \pm 0.68^{\mathrm{b}}$ \\
\hline $18: 2 n-6$ linoleic acid & $19.48 \pm 1.03^{\mathrm{ns}}$ & $16.53 \pm 0.70^{\mathrm{ns}}$ & $16.78 \pm 1.88^{\mathrm{ns}}$ & $16.53 \pm 0.37^{\mathrm{ns}}$ \\
\hline $18: 3 n$-3 linolenic acid & $0.26 \pm 0.04^{\mathrm{ns}}$ & $0.33 \pm 0.02^{\mathrm{ns}}$ & $0.32 \pm 0.03^{\mathrm{ns}}$ & $0.30 \pm 0.02^{\mathrm{ns}}$ \\
\hline $20: 0$ arachidic acid & $0.55 \pm 0.04^{\mathrm{ns}}$ & $0.42 \pm 0.06^{\mathrm{ns}}$ & $0.57 \pm 0.07^{\mathrm{ns}}$ & $0.43 \pm 0.05^{\mathrm{ns}}$ \\
\hline $20: 4 n-6$ arachidonic acid & $15.58 \pm 0.96^{\mathrm{b}}$ & $20.99 \pm 1.09^{b}$ & $21.14 \pm 0.77^{\mathrm{a}}$ & $21.74 \pm 0.95^{\mathrm{a}}$ \\
\hline $22: 0$ behenic acid & $0.99 \pm 0.08^{\mathrm{a}}$ & $0.86 \pm 0.05^{\mathrm{ab}}$ & $0.70 \pm 0.06^{\mathrm{cb}}$ & $0.66 \pm 0.05^{\mathrm{c}}$ \\
\hline $20: 5 n$-3 ecosapentaenoic & $2.73 \pm 0.51^{\mathrm{a}}$ & $0.87 \pm 0.17^{\mathrm{b}}$ & $0.74 \pm 0.20^{\mathrm{b}}$ & $0.73 \pm 0.22^{\mathrm{b}}$ \\
\hline $22: 6 n-3$ docosahexaenoic acid & $11.98 \pm 0.46^{\mathrm{ns}}$ & $10.26 \pm 0.94^{\mathrm{ns}}$ & $10.51 \pm 0.53^{\mathrm{ns}}$ & $10.72 \pm 1.20^{\mathrm{ns}}$ \\
\hline Total saturated & $41.44 \pm 0.94^{\mathrm{ns}}$ & $43.29 \pm 0.49^{\text {ns }}$ & $43.21 \pm 1.04^{\mathrm{ns}}$ & $43.56 \pm 0.18^{\mathrm{ns}}$ \\
\hline Total unsaturated & $58.56 \pm 0.94^{\mathrm{ns}}$ & $56.71 \pm 0.49^{\mathrm{ns}}$ & $56.79 \pm 1.04^{\mathrm{ns}}$ & $56.44 \pm 0.18^{\mathrm{ns}}$ \\
\hline Total monoenes & $8.53 \pm 0.80^{\mathrm{ns}}$ & $7.73 \pm 0.84^{\mathrm{ns}}$ & $7.29 \pm 0.48^{\mathrm{ns}}$ & $6.42 \pm 0.62^{\mathrm{ns}}$ \\
\hline Total PUFA $n-3$ & $14.97 \pm 0.72^{\mathrm{a}}$ & $11.46 \pm 1.08^{\mathrm{b}}$ & $11.58 \pm 0.65^{\mathrm{b}}$ & $11.75 \pm 1.34^{\mathrm{b}}$ \\
\hline Total PUFA $n-6 \%$ & $35.06 \pm 1.15^{\mathrm{ns}}$ & $37.52 \pm 1.01^{\mathrm{ns}}$ & $37.92 \pm 1.24^{\mathrm{ns}}$ & $38.27 \pm 0.81^{\mathrm{ns}}$ \\
\hline$n-6: n-3$ ratio & $2.40 \pm 0.20^{\mathrm{ns}}$ & $3.54 \pm 0.50^{\mathrm{ns}}$ & $3.36 \pm 0.27^{\mathrm{ns}}$ & $3.71 \pm 0.66^{\mathrm{ns}}$ \\
\hline Unsat: Sat & $1.42 \pm 0.06^{\mathrm{ns}}$ & $1.31 \pm \mathrm{v} 0.03^{\mathrm{ns}}$ & $1.32 \pm 0.05^{\mathrm{ns}}$ & $1.30 \pm 0.01^{\mathrm{ns}}$ \\
\hline Poly: Sat ratio & $1.21 \pm 0.04^{\mathrm{ns}}$ & $1.13 \pm 0.03^{\mathrm{ns}}$ & $1.15 \pm 0.06^{\mathrm{ns}}$ & $1.15 \pm 0.02^{\mathrm{ns}}$ \\
\hline
\end{tabular}

Values with different superscripts within rows are significantly different at $P<0.05$; ns no significant difference; ND: not detected.

acids profiles. This effect was not a simple function of the quantity of ALA available, as the high soyabean oil on Diet $6: 1$ and $30: 1$ group had the lowest EPA content, suggesting that the synthesis of LC $n$-3 PUFA may be suppressed in rats by a high LA diet but that this can be overcome by increasing the ALA content of the diet. These observations are in accordance with those in human studies, where increased dietary ALA has been demonstrated to result in significantly increased plasma EPA status, but without an associated increase in plasma DHA status $[8,9]$.

The plasma and adipose tissue fatty acid composition not only reflect the composition of the diet to a large extent, but also reflect de novo fatty acids synthesis coupled with chain elongation and desaturation [4]. The earlier results of this study showed that the CLO contains a higher percentage of total $n$-3 PUFA, linolenic acid (ALA, $n-3$ ), and docosahexaenoic acid (DHA, $n$-3), whereas soybean oil (SO) contains a higher percentage of linoleic acid (LA, n-6) and total $n-6$ PUFA which agrees with previous studies $[10,11]$. Existing data indicates that the fatty acid composition of human plasma lipids is significantly altered during pregnancy [12-14]. Pregnant animals had been identified to have significant effects upon plasma and liver fatty acid composition, including increases in DHA status [15-17]. Thus, the current study confirmed that supplementing dietary fatty acids significantly altered plasma and tissue fatty acid composition, particularly for the DHA and AA. In addition, in this study, the arachidonec acid (AA) content of tissues in pregnancy in the Diet 30:1 group was markedly increased, which indicates that maternal long chain $n-6$ PUFA (linoleic acid) synthesis is also significantly affected by the pregnancy. The effect of pregnancy upon arachidonic acid status was tissue specific and indicates that this fatty acid may be preferentially mobilised into the maternal plasma in order to be available to the fetus. There was an indication that the linoleic acid $(n-6)$ content of plasma fatty acids is higher at day 15 of gestation in the Diet $30: 1$ groups, which may indicate either increased mobilisation of ALA from adipose tissue or lower rates of LC $n$-3 PUFA synthesis at this point of gestation.

Dietary $n$-3 PUFA in Diet 1:1 group had the highest eicosapentaenoic acid (EPA) and docosahexaenoic acid (DPA) content in all plasma fatty acids fractions as compared to other groups, and high level of arachidonic acid (AA) in plasma of Diet $30: 1$ and Diet $6: 1$ groups. This can be explained by the inhibitory effect of cod liver oil on the enzymes involved in the synthesis of AA from linoleic acid (LA). Reference [18] has shown an inhibiting effect of long-chain (LC) $n-3$ fatty acids on delta 6 desaturase activities and subsequently reduction in AA level in plasma of rats supplemented with cod liver oil [19] observed a greater integration of EPA and lower levels of arachidonic acid in brain fatty acids in rats fed fish oil and [20], reported incorporation of docosahexaenoic acid (DHA) into cardiac organelles. It is well known that plasma and tissue fatty acids profile followed that of the diet $[3,10]$, as well as providing precursors or substrates. The $n-3$ and $n-6$ PUFAs interact and compete with 
TABLE 4: Adipose tissue fatty acid composition (mg/100 mL; Mean \pm SE; $n=7)$ of rats from diffrent treatment groups after 10 weeks of feeding.

\begin{tabular}{|c|c|c|c|c|}
\hline \multirow{2}{*}{ Fatty acid composition sample (mg/100 g) } & \multicolumn{4}{|c|}{ Group } \\
\hline & $\operatorname{Diet}(1: 1)$ & $\operatorname{Diet}(6: 1)$ & $\operatorname{Diet}(30: 1)$ & Diet (control) \\
\hline 12:0 lauric acid & $0.06 \pm 0.00^{\mathrm{b}}$ & $0.07 \pm 0.00^{\mathrm{b}}$ & $0.05 \pm 0.00^{\mathrm{b}}$ & $0.08 \pm 0.01^{\mathrm{a}}$ \\
\hline $14: 0$ myristic acid & $1.11 \pm 0.02^{\mathrm{a}}$ & $0.66 \pm 0.04^{\mathrm{bc}}$ & $0.59 \pm 0.05^{c}$ & $0.77 \pm 0.04^{\mathrm{b}}$ \\
\hline 16: 0 palmitic acid & $17.67 \pm 0.24^{\mathrm{bc}}$ & $18.69 \pm 1.23^{\mathrm{ab}}$ & $16.05 \pm 0.61^{\mathrm{c}}$ & $20.79 \pm 1.01^{\mathrm{a}}$ \\
\hline $16: 1$ palmitoleic acid & $1.73 \pm 0.09^{\mathrm{ab}}$ & $1.45 \pm 0.31^{\mathrm{cb}}$ & $0.89 \pm 0.06^{\mathrm{c}}$ & $2.23 \pm 0.39^{\mathrm{a}}$ \\
\hline $18: 0$ stearic acid & $4.25 \pm 0.08^{\mathrm{a}}$ & $4.09 \pm 0.08^{\mathrm{ab}}$ & $3.89 \pm 0.07^{\mathrm{a}}$ & $3.95 \pm 0.16^{\mathrm{ab}}$ \\
\hline $18: 1$ oleic acid & $34.61 \pm 0.23^{\mathrm{ab}}$ & $33.52 \pm 0.60^{\mathrm{cb}}$ & $33.04 \pm 0.24^{\mathrm{c}}$ & $35.58 \pm 0.73^{\mathrm{a}}$ \\
\hline $18: 2 n-6$ linoleic acid & $34.10 \pm 0.31^{\mathrm{cb}}$ & $36.66 \pm 1.76^{\mathrm{ab}}$ & $40.56 \pm 0.88^{\mathrm{a}}$ & $31.94 \pm 1.87^{c}$ \\
\hline $18: 3 n-3$ linolenic acid & $0.21 \pm 0.01^{\mathrm{ns}}$ & $0.23 \pm 0.01^{\mathrm{ns}}$ & $0.21 \pm 0.02^{\mathrm{ns}}$ & $0.23 \pm 0.01^{\mathrm{ns}}$ \\
\hline $20: 0$ arachidic acid & $1.95 \pm 0.06^{\mathrm{ab}}$ & $1.89 \pm 0.19^{\mathrm{b}}$ & $2.01 \pm 0.03^{\mathrm{a}}$ & $1.58 \pm 0.16^{\mathrm{b}}$ \\
\hline $20: 4 n-6$ arachidonic acid & $0.09 \pm 0.07^{\mathrm{b}}$ & $0.67 \pm 0.09^{\mathrm{a}}$ & $0.67 \pm 0.03^{\mathrm{a}}$ & $0.63 \pm 0.04^{\mathrm{c}}$ \\
\hline $22:$ behenic acid & $0.19 \pm 0.01^{\mathrm{b}}$ & $0.23 \pm 0.02^{\mathrm{a}}$ & $0.22 \pm 0.00^{\mathrm{ab}}$ & $0.19 \pm 0.01^{\mathrm{ab}}$ \\
\hline $22: 1$ erucic acid & $0.03 \pm 0.00^{\mathrm{a}}$ & $0.02 \pm 0.01^{\mathrm{b}}$ & $0.04 \pm 0.00^{\mathrm{a}}$ & $0.02 \pm 0.01^{\mathrm{b}}$ \\
\hline $20: 5 n$-3 ecosapentaenoic acid & $0.35 \pm 0.04^{\mathrm{a}}$ & $0.09 \pm 0.01^{\mathrm{b}}$ & $0.08 \pm 0.02^{\mathrm{b}}$ & $0.08 \pm 0.02^{\mathrm{b}}$ \\
\hline $22: 6 n-3$ docosahexaenoic acid & $1.32 \pm 0.14^{\mathrm{a}}$ & $0.41 \pm 0.09^{\mathrm{b}}$ & $0.47 \pm 0.08^{\mathrm{b}}$ & $0.31 \pm 0.07^{\mathrm{b}}$ \\
\hline Total saturated & $25.98 \pm 0.18^{\mathrm{a}}$ & $26.33 \pm 1.14^{\mathrm{a}}$ & $23.38 \pm 0.70^{\mathrm{b}}$ & $28.23 \pm 1.01^{\mathrm{a}}$ \\
\hline Total unsaturated & $74.02 \pm 0.18^{\mathrm{b}}$ & $73.67 \pm 1.14^{\mathrm{b}}$ & $76.62 \pm 0.70^{\mathrm{a}}$ & $71.77 \pm 1.01^{\mathrm{c}}$ \\
\hline Total monoenes & $36.94 \pm 0.30^{\mathrm{a}}$ & $35.61 \pm 0.84^{\mathrm{cb}}$ & $34.63 \pm 0.17^{\mathrm{ab}}$ & $38.57 \pm 1.11^{\mathrm{a}}$ \\
\hline Total PUFA $n-3$ & $1.88 \pm 0.17^{\mathrm{a}}$ & $0.73 \pm 0.11^{\mathrm{b}}$ & $0.76 \pm 0.07^{\mathrm{b}}$ & $0.62 \pm 0.09^{\mathrm{b}}$ \\
\hline Total PUFA $n-6$ & $36.19 \pm 0.35^{\mathrm{b}}$ & $37.33 \pm 1.78^{\mathrm{ab}}$ & $41.23 \pm 0.87^{\mathrm{a}}$ & $32.57 \pm 1.87^{c}$ \\
\hline$n-6: n-3$ ratio & $19.50 \pm 1.50^{\mathrm{b}}$ & $59.44 \pm 10.49^{b}$ & $57.96 \pm 6.91^{\mathrm{a}}$ & $57.33 \pm 6.12^{\mathrm{a}}$ \\
\hline Unsat: Sat & $2.85 \pm 0.03^{\mathrm{b}}$ & $2.84 \pm 0.16^{\mathrm{b}}$ & $3.30 \pm 0.12^{\mathrm{a}}$ & $2.57 \pm 0.13^{\mathrm{b}}$ \\
\hline Poly: Sat ratio & $1.43 \pm 0.03^{\mathrm{b}}$ & $1.48 \pm 0.12^{\mathrm{b}}$ & $1.81 \pm 0.09^{\mathrm{a}}$ & $1.20 \pm 0.12^{\mathrm{b}}$ \\
\hline
\end{tabular}

Values with different superscripts within rows are significantly different at $P<0.05$; ${ }^{\text {ns }}$ no significant difference; ND: not detected.

each other for incorporation into phospholipids and as substrates for metabolic enzymes (especially desaturase and COX) [21-23]. Changes in the amounts of PUFAs or their ratios may affect production of PGs in the reproductive system in both cows [24] and humans [25].

Diet supplemented with $n-3$ PUFA has been shown to inhibit $\Delta 6$ desaturase activity [26]. Potential explanation of the elevation of plasma LA levels with elevated n-3 PUFA ingestion has been reported previously $[27,28]$. In the present study, increasing LA levels in Diet 30:1 group led to an increase in plasma LA level. When feeding soybean oil as a source of the arachidonic acid precursor (LA), there was a significant increase in plasma AA content. This increase is in agreement with [10] who feed the rats with high level of safflower oil.

\section{Conclusion}

In this study, diets with higher PUFA $n-6: n-3$ ratios resulted in higher AA and lower DHA levels in plasma. It is important to consider that the circulating concentrations of fatty acids such as DHA during pregnancy will be affected by the transfer of fatty acids to the developing fetus in pregnant rat. This study also successfully demonstrated the changes induced by varying levels of dietary $n-6: n-3$ PUFA ratio on plasma and tissue fatty acid contents in pregnant rat.

\section{References}

[1] H. W. Cook, "Chapter 5 Fatty acid desaturation and chain elongation in eukaryotes," New Comprehensive Biochemistry, vol. 31, pp. 129-152, 1996.

[2] V. M. Sardesai, "Nutritional role of polyunsaturated fatty acids," The Journal of Nutritional Biochemistry, vol. 3, no. 4, pp. 154-166, 1992.

[3] A. I. Mohamed, A. S. Hussein, S. J. Bhathena, and Y. S. Hafez, "The effect of dietary menhaden, olive, and coconut oil fed with three levels of vitamin $\mathrm{E}$ on plasma and liver lipids and plasma fatty acid composition in rats," The Journal of Nutritional Biochemistry, vol. 13, no. 7, pp. 435-441, 2002.

[4] N. Z. Ding, C. B. Teng, H. Ma et al., "Peroxisome proliferatoractivated receptor delta expression and regulation in mouse uterus during embryo implantation and decidualization," Molecular Reproduction and Development, vol. 66, no. 3, pp. 218-224, 2003.

[5] Y. Wang, D. Botolin, B. Christian, J. Busik, J. Xu, and D. B. Jump, "Tissue-specific, nutritional, and developmental regulation of rat fatty acid elongases," Journal of Lipid Research, vol. 46, no. 4, pp. 706-715, 2005.

[6] J. Folch, M. Lees, and G. H. Solan-Stanley, "A simple method for the isolation and purification of total lipides from animal tissues," The Journal of Biological Chemistry, vol. 226, no. 1, pp. 497-509, 1957.

[7] M. A. Rajion, Essentail fatty acid metabolism in the fetal and newborn lamb, Ph.D. thesis, University of Melbourne, Melbourne, Australia, 1985. 
[8] C. H. S. Ruxton, P. C. Calder, S. C. Reed, and M. J. A. Simpson, "The impact of long-chain $n-3$ polyunsaturated fatty acids on human health," Nutrition Research Reviews, vol. 18, no. 1, pp. 113-129, 2005.

[9] G. C. Burdge and P. C. Calder, "Dietary $\alpha$-linolenic acid and health-related outcomes: a metabolic perspective," Nutrition Research Reviews, vol. 19, no. 1, pp. 26-52, 2006.

[10] D. C. Kevin, J. Lawrence, R. V. Beilin, and M. Elaine, "Dietary modification of fatty acid and prostaglandin synthesis in the rat. Effect of variations in the level of dietary fat," Biochimica et Biophysica Acta, vol. 795, no. 2, pp. 196-207, 1984.

[11] E. Berlin, S. J. Bhathena, D. McClure, and R. C. Peters, "Dietary menhaden and corn oils and the red blood cell membrane lipid composition and fluidity in hyper- and normocholesterolemic miniature swine," The Journal of Nutrition, vol. 128, no. 9, pp. 1421-1428, 1998.

[12] M. D. M. Al, A. C. van Houwelingen, A. D. M. Kester, T. H. M. Hasaart, A. E. P. de Jong, and G. Hornstra, "Maternal essential fatty acid patterns during normal pregnancy and their relationship to the neonatal essential fatty acid status," British Journal of Nutrition, vol. 74, no. 1, pp. 55-68, 1995.

[13] F. Stewart, V. A. Rodie, J. E. Ramsay, I. A. Greer, D. J. Freeman, and B. J. Meyer, "Longitudinal assessment of erythrocyte fatty acid composition throughout pregnancy and post partum," Lipids, vol. 42, no. 4, pp. 335-344, 2007.

[14] P. Weisweiler, P. Janetschek, and P. Schwandt, "Influence of polyunsaturated fats and fat restriction on serum lipoproteins in humans," Metabolism, vol. 34, no. 1, pp. 83-87, 1985.

[15] A. F. Smith, "Ultrastructure of the uterine luminal epithelium at the time of implantation of ageing mice," Journal of Reproduction and Fertility, vol. 42, no. 1, pp. 183-185, 1975.

[16] Z. Y. Chen, J. Yang, and S. C. Cunnane, "Gestational hyperlipidemia in the rat is characterized by accumulation of $n$-6and $n$ 3 fatty acids, especially docosahexaenoic acid," Biochimica et Biophysica Acta, vol. 1127, no. 3, pp. 263-269, 1992.

[17] G. C. Burdge, A. N. Hunt, and A. D. Postle, "Mechanisms of hepatic phosphatidylcholine synthesis in adult rat: effects of pregnancy," Biochemical Journal, vol. 303, no. 3, pp. 941-947, 1994.

[18] E. Berlin, E. J. Matusik, and C. Young, "Effect of dietary fat on the fluidity of platelet membranes," Lipids, vol. 15, no. 8, pp. 604-608, 1980.

[19] J. M. Bourre, G. Pascal, and G. Durand, "Alterations in the fatty acid composition of rat brain cells (neurons, astrocytes, and oligodendrocytes) and of subcellular fractions (myelin and synaptosomes) induced by a diet devoid of $n-3$ fatty acids," Journal of Neurochemistry, vol. 43, no. 2, pp. 342-348, 1984.

[20] M. Croset, J. M. Black, J. E. Swanson, and J. E. Kinsella, "Effects of dietary $n-3$ polyunsaturated fatty acids on phospholipid composition and calcium transport in mouse cardiac sarcoplasmic reticulum," Lipids, vol. 24, no. 4, pp. 278-285, 1989.

[21] S. F. Olsen, J. D. Sørensen, N. J. Secher et al., "Randomised controlled trial of effect of fish-oil supplementation on pregnancy duration," The Lancet, vol. 339, no. 8800, pp. 1003 1007, 1992.

[22] D. R. E. Abayasekara and D. C. Wathes, "Effects of altering dietary fatty acid composition on prostaglandin synthesis and fertility," Prostaglandins Leukotrienes and Essential Fatty Acids, vol. 61, no. 5, pp. 275-287, 1999.

[23] R. Mattos, C. R. Staples, and W. W. Thatcher, "Effects of dietary fatty acids on reproduction in ruminants," Reviews of Reproduction, vol. 5, no. 1, pp. 38-45, 2000.
[24] W. W. Thatcher, C. R. Staples, G. Danet-Desnoyers, B. Oldick, and E.-P. Schmitt, "Embryo health and mortality in sheep and cattle," Journal of Animal Science, vol. 72, article 16, 1994.

[25] S. M. Innis, "Polyunsaturated fatty acids in human milk: an essential role in infant development," Advances in Experimental Medicine and Biology, vol. 554, pp. 27-43, 2004.

[26] M. L. Garg, E. Sebokova, A. B. R. Thomson, and M. T. Clandinin, " $\Delta 6$-Desaturase activity in liver microsomes of rats fed diets enriched with cholesterol and/or $\omega 3$ fatty acids," Biochemical Journal, vol. 249, no. 2, pp. 351-356, 1988.

[27] D. H. Hwang, M. Boudreau, and P. Chanmugam, "Dietary linolenic acid and longer-chain $n$ - 3 fatty acids: comparison of effects on arachidonic acid metabolism in rats," Journal of Nutrition, vol. 118, no. 4, pp. 427-437, 1988.

[28] J. Whelan, K. S. Broughton, B. Lokesh, and J. E. Kinsella, "In vivo formation of leukotriene E5 by murine peritoneal cells," Prostaglandins, vol. 41, no. 1, pp. 29-42, 1991. 

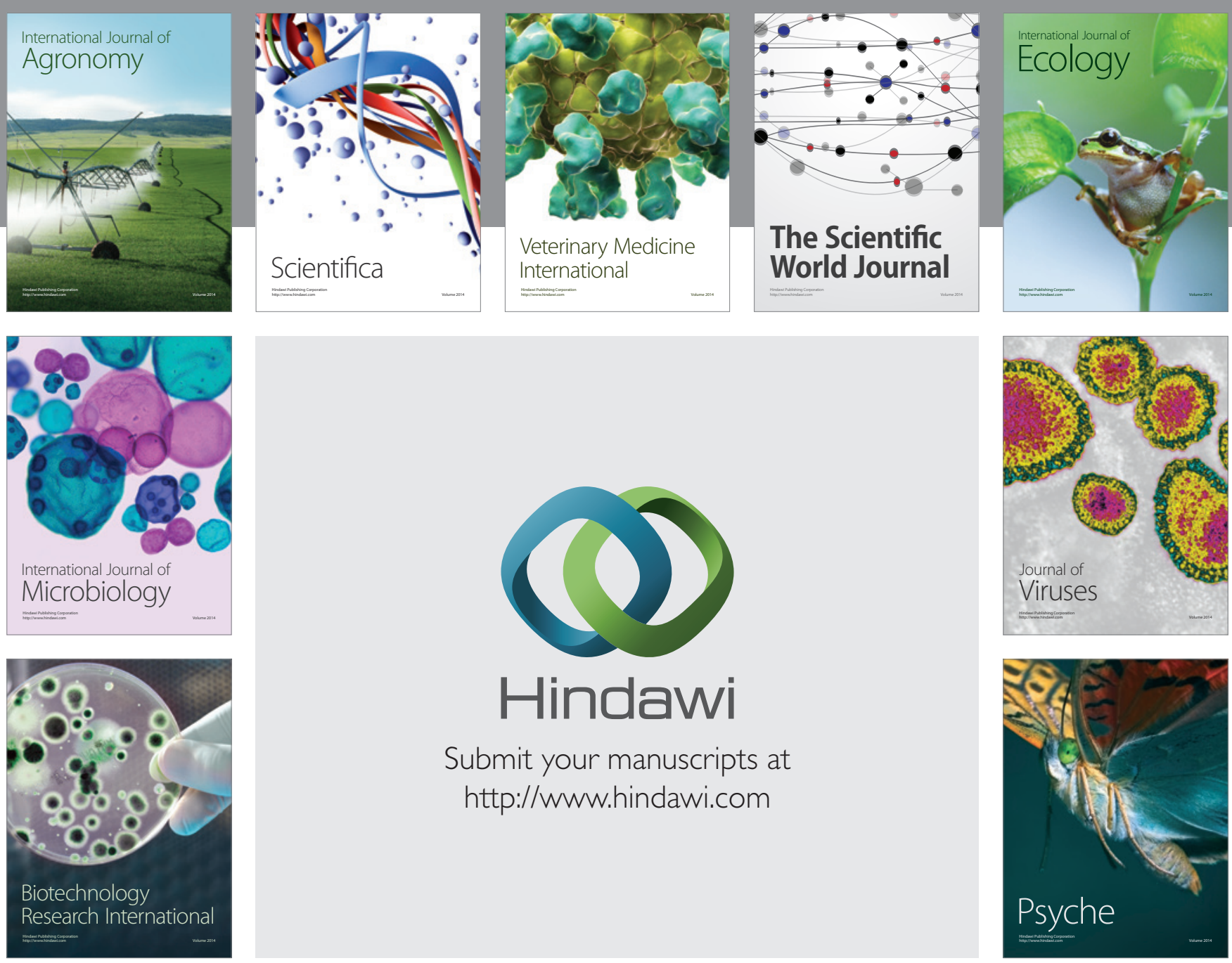

Submit your manuscripts at

http://www.hindawi.com
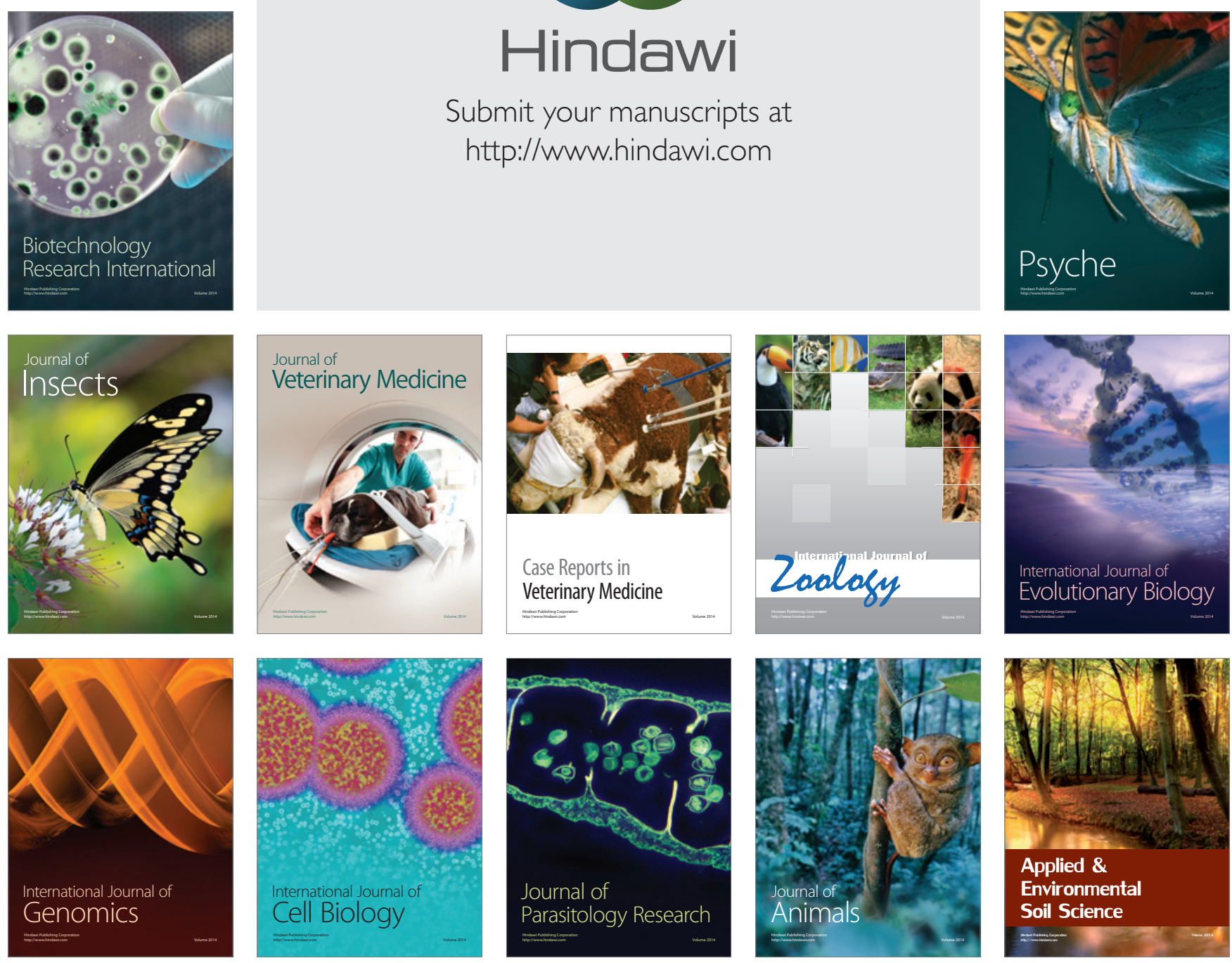